\title{
Kreml, gasledningen og sikkerheden
}

\section{Robert Larsson}

\section{Man kunne måske nøjes med at bekymre sig om miljøproblemerne omkring den påtænkte russisk- tyske gasledning gennem Østersøen, hvis Rusland var ved at udvikle sig til en normal, demokratisk markedsøkonomi - det er ikke tilfældet}

I 2006 kom den planlagte Østersøgasledning Nord Stream (tidligere North European Gas Pipeline) i fokus i den nordiske debat om energi og energisikkerhed. I et strategisk perspektiv er der tale om det vigtigste enkeltspørgsmål for det regionale energisamarbejde. Udviklingen bliver stadig mere interessant, især fordi det internationale energimarked er et hårdt politisk miljø, hvor konkurrencen øges, og hvor geopolitik flettes sammen med miljø- og energisikkerhed. I dette spil bliver $\emptyset$ stersøen en stadig vigtigere kontaktflade mellem Rusland som en førende naturgasproducent og EU, en sammenslutning af storforbrugere, som bliver mere og mere afhængige af russisk gas.

Når Nord Stream kommer ind i billedet for at løse en del af problemerne med gasefterspørgslen i Europa, rokkes der samtidig ved sikkerhedsarkitekturen i Østersøområdet. En analyse af spørgsmålet om gasledningen bør derfor ikke kun ses udfra det europæiske eller fx det tyske forbrugsperspektiv, som er det perspektiv, der almindeligvis holdes frem af Nord Stream, men også ses på baggrund af projektets uigennemskuelighed og Ruslands udenrigs-, sikkerheds- og energipolitik.

Et centralt udgangspunkt for denne analyse er, at den russiske politiske ledelse har bestemt sig for at forsøge at skabe stabilitet i landet, få kontrol over strategiske reserver samt genoprette Ruslands status som stormagt. Kremls afvejninger, prioriteringer og metoder for at nå 
disse mål har imidlertid ført Rusland bort fra det spirende demokrati og den gryende markedsøkonomi, som man så i Jeltsin-æraen. Da den russiske økonomi er stærkt afhængig af eksportindtægterne fra kulbrintebaserede energiråstoffer, bliver energipolitikken et af præsidentens vigtigste midler til at nå statens overordnede økonomiske mål. Men energipolitikken skal ikke kun bringe velstand til Rusland; den ses også som et sikkerhedspolitisk instrument.

Den russiske energistrategi fra 2003 siger $\mathrm{fx}$, at energipolitikkens "fundamentale formål er at gavne den nationale sikkerhed". Dette skal ske ved at øge Ruslands indflydelse i udlandet og imødegå geopolitiske, makroøkonomiske og andre trusler. Afhængighed af tredjeland på energieksportens vej til aftagermarkederne regnes blandt sådanne trusler, $\mathrm{og}$ Nord Stream skal imødegå denne trussel ved at Rusland spreder eksportruterne.

Det grundlæggende motiv bag gasledningen er således en russisk ambition om at kunne vælge mellem aftagere af gassen, en ambition som er neomerkantilistisk i sin karakter og udtryk for en stræben efter at være uafhængig af omverdenen, samtidig med at omverdenen helst skal være afhængig af Rusland. Derfor har den russiske statsledelse i højere grad end tidligere gjort energispørgsmålet til et sikkerhedsspørgsmål.

Dette er en af flere grunde til, at den russiske sikkerhedstjeneste FSB, efterretningstjenesten SVR (begge tidligere dele af KGB) samt forsvaret har fået øget ansvar for økonomiske spørgsmål og beskyttelse af russiske økonomisk-strategiske interesser som fx energi-infrastruktur.

Rusland har altså, som det selv ser det, etableret en legitim grund til at behandle energispørgsmål som sikkerhedsspørgsmål, hvilket skaber accept inden for statsforvaltningen og i befolkningen af, at energipolitiske mål forfølges med stor styrke. Et af de vigtigste instrumenter hertil er det statskontrollerede gasmonopol Gazprom, foretagendet bag Nord Stream. På denne baggrund søger denne artikel at fremhæve et par af gasledningens konsekvenser, især i et svensk perspektiv.

\section{Miljøet og koblingen til Kreml}

Rusland og Tyskland har altså besluttet sig for at bygge en $1.200 \mathrm{~km}$ lang gasledning fra Viborg i Den Finske Bugt gennem Østersøen til Greifswald i Tyskland, eller evt. endnu længere. $482 \mathrm{~km}$ af ledningen skal gå gennem Sveriges $\varnothing$ konomiske zone, og en 35 meter høj serviceplatform skal bygges ca. $40 \mathrm{~km}$ øst for Gotland.

Sverige har endnu ingen officiel politik vedrørende ledningen som sådan; med den tidligere regering og flere af den nuværende regerings medlemmer har ytret sig imod svensk tilslutning til ledningen, bå- 
de af frygt for leverancesikkerheden og fordi man vil prioritere den hjemlige biobrændselssektor.

I svensk presse i 2006 og 2007 er det endvidere fremgået, at repræsentanter for erhvervslivet var relativt positive over for ledningen, mens der har været tegn på en vis uro blandt sikkerhedspolitiske analytikere og i befolkningen. Uroen i befolkningen, især på Gotland, skyldes ledningens trussel mod miljøet.

Koncentrationen af tungmetaller og fx PCB langs den planlagte linjeføring vil blive revet op i forbindelse med byggeriet. Mindst 15 større områder med udetonerede miner og dumpede kemiske kampstoffer (bl.a. sennepsgas og Zyklon B) ligger i vejen. Fiskebestanden og fiskeriet vil blive påvirket, ligesom kulturarven. Det er ikke hidtil lykkedes Nord Stream at gøre rede for, hvordan man vil håndtere disse problemer på en tilfredsstillende måde, og det har medført en vis mistillid til projektet.

En dybereliggende årsag til mistilliden skal måske findes i ejerkredsen og dens kobling til Kreml. De tyska selskaber EON og BASF (samt datterselskaberne Ruhrgas og Wintershall) ejer 49 procent af konsortiet, og Gazprom ejer de resterende 51 procent, og således har Nord Stream repræsentanter for såvel Gazprom som EON og BASF i bestyrelsen. Gazprom på sin side ejes for 51 procents vedkommende af den russiske stat.
Man kan dog ikke, som visse analytikere, deraf slutte, at den russiske stats indflydelse på Nord Stream kun er 26 procent. Den uformelle styring er langt stærkere end som så; sammenvævningen med staten er stærk. I Gazproms bestyrelse sidder bl.a. økonomiminister German Gref, energiminister Viktor Khristenko, præsident Putins særlige repræsentant i energispørgsmål Igor Jusufov samt første vicepremierminister Dmitrij Medvedev. Den administrerende direktør Aleksej Miller er desuden en god ven af Putin.

Men også andre personforbindelser i selskabet har vakt opmærksomhed i pressen. Gerhard Schröder er bestyrelsesformand og den administrerende direktør hedder Mattias Warnig. Warnig arbejdede for Stasi i Dresden samtidig med at Putin arbejdede der for KGB. Flere kilder hævder, at de kendte hinanden, hvilket de dog benægter. Warnig har endvidere været chef for Dresdner Banks ruslandsafdeling, som foretog vurderingen af olieselskabet Yukos, da dets mest lønsomme dele i realiteten blev eksproprieret af den russiske stat. I åbne kilder finder man ingen beviser for, at disse personforbindelser skulle medføre juridiske uregelmæssigheder; men situationen indbyder til at sætte spørgsmålstegn ved projektets gennemskuelighed, politiske bevæggrunde og korruptionsrisici.

På tysk side har en diskutabel faktor været, at Europa-Kommissionen 
har igangsat en undersøgelse af, om der er tale om ulovlig tysk statsstøtte til projektet, noget der synes at hænge sammen med, at Gerhard Schröder gav bankgarantier på omkring én milliard euro til projektet kun en måned før sin afgang som tysk forbundskansler. Dette har ødelagt den tillidsskabende effekt, som det måske kunne have haft, at han blev formand for bestyrelsen i Nord Stream.

Eftersom Gazprom direkte eller indirekte kommer til at stå for prospektering, design, konstruktion, drift og overvågning af gasledningen, er den russiske partner i projektet den vigtigste, selv om ingen russiske repræsentanter har optrådt i kontakten til Sverige og andre $\varnothing$ øtesøstater. Et vigtigt aspekt i sammenhængen er, at Gazprom kun delvis gør rede for sin ejerandel i andre selskaber. Således ejes eller kontrolleres selv tilsyneladende uafhængige selskaber nogle gange af Gazprom. Betydningen af dette skal ikke undervurderes, da Gazprom gentagne gange har benyttet sig af tvivlsomme datterselskaber, mellemmænd og underleverandører (fx Rosukrenergo, Trubnij Torgovij Dom og Eural Trans Gas) til såvel økonomiske som politiske formål.

Disse og andre lignende selskaber skal således ikke forstås som fritstående og rent markedsdrevne foretagender, selv om de har en profitinteresse. Ofte tvinges de til markedsmæssigt usunde dispositioner af politiske grunde.
Der findes ganske vist helt fritstående russiske energiproducenter; men de agerer først og fremmest i lille skala, og den russiske stat sidder meget hårdt på kontrollen over gaseksporten. Med en enkelt undtagelse har der ikke været privat kontrollerede rørledninger i Rusland, hvor ledningssystemet ejes og drives af Gazprom og dets forskellige selskaber. I 2007 bliver det lovfæstet, at kun statsejede ledninger er tilladt, hvilket yderligere styrker Kremls greb om eksporten.

Hvis Rusland udviklede sig i demokratisk og markedsøkonomisk retning, ville disse problemer i det store og hele være ikke-spørgsmål. Men de politiske skyer, som trækker op nu, er urovækkende, i vort tilfælde fordi Nord Stream først og fremmest handler om gastransport.

Gennemskuelighedsproblemerne omkring Nord Stream og Gazprom er således betydelige. Ejerstrukturen, aktiebogen og årsregnskabet har alle mangler, og i kombination med den russiske stats krav om hemmeligholdelse, bl.a. i medfør af loven om statshemmmeligheder, er det meget svært at få indsigt i disse selskaber og deres ressouncer. Dette er af allerstørste betydning, når det gælder den planlagte gasledning og anvendelsen af datterselskaber og kontraktsforhold, fordi der kan opstå tvivl om ansvarsforhold. Det vil fx kunne skabe vanskeligheder, hvis Gazprom ejer offshore-registrerede selskaber, som på deres side ejer 
virksomhedsudøvende selskaber, som udfører arbejde for Nord Stream. Da vil der være en risiko for, at Nord Stream anvender underleverandører, datterselskaber eller underentreprenører for at unddrage sig ansvar i visse miljøspørgsmål.

\section{Problemer, men ingen indtægter}

Som antydet er der implikationer også på det forsvarspolitiske område. Rusland skal bygge og drive ledningen, og det er fuldt ud muligt, at Rusland kan anvende ledningen og servicetårnet som efterretningsplatform ved at montere aflytningsudstyr, side-scan sonarsystemer, magnetometre, hydrofoner og militære radarsystemer - eller ganske enkelt dobbeltudnytter civile drifts- og vedligeholdelsessystemer til efterretningsindhentning.

Hvis denne derefter matches med kendte fartøjsregistre og anden information, vil ledningen fungerer som et snubletrådssystem, som kan overvåge al søtrafik, såvel under som på overfladen, $\mathrm{fx}$ ud for Sverige og $\mathrm{i}$ Den Finske Bugt. Ledningen skal gå lige uden for det finske forsvars øvelsesområder, så hvis det russiske forsvar får adgang til information af denne art, kan det overvåge Sveriges, Finlands og NATOs øvelser og aktivitet uden selv at have orlogsfartøjer eller ubåde i nærheden.

Det ville være en overdrivelse at kalde dette en militær trussel; men et tilsvarende 'vindueskiggeri' fyrre kilometer fra fx Kaliningrad ville Rusland ikke tillade. Samtidig skal man huske på, at Putin har lovet, at den russiske Østersøflåde vil beskytte ledningen, og der er således risiko for en fornyet militarisering af $\emptyset$ stersøen.

Den russiske Østersøflåde består i dag af 56 orlogsfartøjer, hvoraf kun halvdelen er fuldt operative; men flåden er blevet opprioriteret på samme måde som de strategiske raketstyrker. Med nye bevillinger og nyt materiel sker der en stadig styrkelse af dens evne til kystnære magtdemonstrationer. Finland, Estland og Sverige kan dermed regne med øget russisk militær tilstedeværelse langs deres kyster, en situation som få nationer ville bryde sig om, uanset hvilke naboer de har. Den juridiske mulighed herfor findes naturligvis allerede i dag; men Nord Stream giver Rusland en anledning til forøget tilstedeværelse, en anledning som vil kunne misbruges.

Hvis desuden den planlagte serviceplatform bemandes af russisk personel, vil der sikkert følge russiske krav om ret til selv at forsvare den, skønt beskyttelsen af den ville være Sveriges juridiske ansvar. Kremls retorik når det gælder beskyttelse af egne borgere er meget hård, hvilket bl.a. Letland og Georgien har fået at føle, og i en krisesituation, fx i forbindelse med en terrorbegivenhed, ville presset øge mærkbart.

Med Nord Stream stiger altså risikoen for forsvarspolitiske gnidnin- 
ger i Sveriges nærområde. Nord Stream vurderer helt korrekt at risikoen for terrorisme lige nu ikke er overhængende; men man må i den sammenhæng huske, at ledningen skal være operativ i 50 år.

Med tanke på udviklingen i Rusland og Europa de sidste 50 år i kombination med en højst uforudsigelig russisk udvikling kan man spørge, om det er en risiko, som $\emptyset$ stersøstaterne er villige til at tage, især da Moskvas krig mod Tjetjenien og håndfaste udenrigspolitik formentlig øger sandsynligheden for et terroristangreb mod russiske interesser. I vid udstrækning ville håndteringen af et attentat mod platformen blive Sveriges hovedpine.

\section{Geopolitikken}

Ser man på det overordnede sikkerheds- og geopolitiske niveau, skærer ledningen som en sløv kniv gennem $\varnothing$ østersøen og deler EU i to lejre. Tyskland og delvis Frankring, Danmark og Nederlandene er for projektet i visse tilfælde, eftersom de kan få en del af den importerede gas. Polen, Estland, Letland, Litauen, Finland og Sverige har været skeptiske eller direkte negative. Projektet splitter således Østersølandene og gør det sværere at etablere en fælles og solidarisk energipolitik i EU, hvilket passer Rusland fint. Nord Stream er et klart eksempel på den tiltagende bilateralisme, som man ser inden for den globale ener- gipolitik, i hovedsagen på bekostning af fælles, tillidsskabende og markedsbaserede initiativer.

Rusland kan med Nord Stream lukke for gassen til Ukraine eller Hviderusland, uden at vigtigere kunder som fx Tyskland rammes som under gaskriserne i januar og december 2006 (Nord Stream kan sende gas direkte til Tyskland). Tilsvarende kan Rusland presse prisen på transitten, når eksporten går gennem tredjeland, og dermed forsvinder et af Polens stærkeste kort i energirelationerne med Rusland.

De nye EU-medlemmers aversion mod at blive afhængige af Rusland skyldes ikke bare deres erfaringer med at være underlagt Sovjetunionen, men har også aktuel baggrund i det moderne Ruslands hårdhændede energipolitik, specielt i kombination med en lidet attraktiv udvikling i russisk udenrigspolitik, en tydelig genoprustning af russisk militær og Kremls ambition om at genvinde sin stormagtsstatus.

Rusland vil fx få adgang til aftagermarkederne og vigtige anlæg som Ventspils havn i Letland og Mazeiku-raffinaderiet i Litauen, samtidig med at udenlandsk indflydelse på det russiske marked begrænses. Ruslands argument er, at dette er den eneste vej til energisikkerhed. Problemet for en stat som Litauen er, at hvis man følger en konstruktiv linje, virker man svag og vil straks blive presset til eftergivenhed; men indtager man en fastere 
position, kan olieleverancerne hurtigt blive stoppet.

Omfanget af disse problemer er i visse henseender vokset med årene, fordi Rusland siden 1991 bl.a. har gennemført midlertidige leveringsstop eller ført hårdhændet energipolitik i henved tres tilfælde over for sine svagere nabolande, deriblandt Estland, Letland, Litauen, Hviderusland, Ukraine, Moldova og Georgien. Økonomi, energi og magtpolitik flyder sammen i russisk energipolitik, og så sent som i maj sagde Ruslands ambassadør i Kiev, at Ukraine må være forberedt på at ændre sin pro-vestlige politik, hvis man vil have en lav gaspris. Der er altså en vis risiko for, at Rusland misbruger sin energipolitik, og så vil de svageste og mest afhængige stater være værst stillet. Dette er naturligvis en faktor, der skal regnes med, hvis en stat som Sverige overvejer at øge sit naturgasforbrug, selv om Sverige måske står stærkere end fx Letland.

Et andet aspekt som er værd at trække frem på europæisk plan, er at tendensen går i retning af, at den importerede mængde af russisk gas vil stige, især i Øst- og Centraleuropa; men da det totale gasbehov kommer til at øge meget kraftigt, vil afhængigheden af Nordafrika og Mellemøsten relativt stige mest. I den sammenhæng bør det dog understreges, at russiske selskaber opkøber store reserver i og omkring Europa, og at Ruslands betydning for Europa således øger mere, end det umiddelbart kunne se ud til. Når dette sker, og når den regionale energipolitik aftales mellem Rusland og de store EU-medlemmer, bliver det stadig sværere for svage stater som Estland, Letland og Litauen at blive netto-bidragsydere til den regionale sikkerhedsarkitektur, som blev skabt efter afslutningen af den Kolde Krig. Deres afhængighed reducerer ganske enkelt deres internationale manøvrerum.

De russisk-europæiske energirelationer er selvsagt baseret på en vis gensidig afhængighed, da Europa er afhængig af russisk gas og Rusland til gengæld afhængig af indtægterne fro olie- og gaseksporten til Europa. Der forekommer dog visse asymmetrier, da Ruslands følsomhed over for bortfald af disse indkomster er mindre end følsomheden hos en specifik importør for bortfald af leverancer. Estland, Letland, Litauen, Polen og Finland er betydeligt mere afhængige end Europa som helhed, omend Finland er noget mindre sårbart end de øvrige, fordi Finlands økonomi er stærkere end deres.

\section{Energisikkerheden i perspektiv}

Det kan i sammenhængen være på sin plads at se nærmere på begrebet energisikkerhed (energy secyrity), som for tiden er på alles læber, skønt dets betydning varierer, afhængigt af hvem der bruger det. For nogle analytikere betyder det kun forsyningssikkerhed (security of supply), som er 
en så smal definition, at den kun er brugbar, når man skal analysere fx nationale elkraftsystemers sårbarhed. Energisikkerhed kan også vedrøre energirelateret infrastruktur, fx at en rørledning skal have indbygget sikkerhed for mennesker og miljø (energy safety), men også energileverandørens $\varnothing$ konomiske og politiske pålidelighed (energy reliability). For Rusland indebærer energisikkerhed på den anden side også sikker adgang til eksportmarkederne for olie og gas. Forskellen på synsvinklerne kommer til udtryk ved at de centrale aktører forholder sig forskelligt til energipolitikken og handler med forskellige bevæggrunde.

Et centralt eksempel i denne sammenhæng er, at stater som $\mathrm{fx}$ USA og Kina, som er nettokonsumenter, gør sig kraftigt gældende for at sikre deres adgang til olie og gas, mens Rusland og Venezuela som producenter udnytter energipolitikken som et magtredskab for at opnå økonomiske eller politiske fordele.

Alle producenter handler dog ikke på samme baggrund. Da Rusland har større strategiske, militære, $\varnothing$ konomiske og politiske interesser i $\emptyset$ stersøen end fx Venezuela eller Saudiarabien, er der strukturelle forklaringer på, at andre drivkræfter end markedsøkonomiske er retningsgivende for den russiske politik i regionen. Et resultat er, at det er lettere for en svag stat at have at gøre med det markedsorienterede Norge eller det fjerne Saudi-Arabien end med Rusland. Når Ruslands ressourcer af især olie, men også gas efterhånden mindskes (og det indenlandske forbrug øges eller opprioriteres), vil konkurrencen om det, der bliver tilovers blive meget stærkere end i dag. Denne proces er allerede indledt, og ud over at prisen stiger med øget konkurrence blandt aftagerne, vil Rusland med forbedringer i eksportsystemerne i højere grad kunne tage politiske hensyn ved valg af aftagere af russisk energi.

Da er det ikke urimeligt at antage, at de baltiske stater og Polen som hårde kritikere af Rusland og mindre lukrative markeder vil blive ladt i stikken til fordel for venligtsindede stater som Tyskland. Situationen lægger op til eftergivenhedspolitik, og der er således politiske argumenter mod en øget afhængighed af russisk energi.

Det er en komplicerende omstændighed, at hvis andre EU-importører solidariserer sig med de svagere medlemslande ved at indtage en hård holdning, så øges Ruslands tilbøjelighed til at vende sig bort fra Europa, hvilket Putin eksplicit har truet med, selv om der af tekniske grunde højst kan blive tale om en mindre vægtforskydning i eksportmønstret.

Den kunne for så vidt passe meget godt med en del aftagerlandes tilbøjelighed til at mindske afhængigheden af Rusland; men den er ikke uden problemer. Ganske kort kan man sige, at energisikkerheden kan øges enten på bekostning af økonomien $\mathrm{fx}$ i form af alternative, dyrere 
leverandører eller dyre infrastrukturinvesteringer i fx kernekraft, som er den vej Polen går, eller på bekostning af miljøet bl.a. ved at satse på olieskifer, tjæresand eller andre urene kulbrintekilder, som er den option Estland kigger på. Nabolandene er ikke begejstrede for disse alternativer, og dermed besværliggøres mulighederne for samarbejde.

\section{En energipolitisk bjørnetjeneste}

Et aspekt knyttet til problemerne med energisikkerhed er, at gasledningen i et energipolitisk perspektiv er et tveægget sværd - den løser en del problemer, men skaber samtidig nye. Fuldt udbygget vil ledningen tilføre det europæiske marked 55 mia. $\mathrm{m}^{3} \mathrm{om}$ året, hvilket kan ses som en fordel. Et behov af denne størrelsesorden fremgår af Det Internationale Energiagenturs (IEA's) behovsanalyse for de kommende 20-30 år. Her forudsættes dog 'business as usual' på energimarkedet. IEA har også et alternativt scenarie, hvor praktisk realiserbare alternativer får mere plads. Konklusionen er, at hvis vi tager os tilstrækkeligt sammen, er Nord Stream helt unødvendig.

Et andet argument for ledningen er, at et fornyet tilskud af naturgas vil mindske behovet for øget anvendelse af kul. Det passer i princippet; men man skal være opmærksom på, at mere naturgas mindsker incitamenterne til at satse på en renere kulteknologi (såkaldt CCS: $\mathrm{CO}_{2}$ Cap- ture and Storage) eller på vedvarende energikilder. Det tætte energisamarbejde mellem Rusland og Tyskland medfører desuden, at Ruslands indflydelse på elkraftindustrien i Europa øges. Gennem sameje kan man krydssubventionere sine egne gasfyrede kraftværker og således gøre andre sektorer mindre konkurrencedygtige. En konsekvens af dette er, at andre typer elkraft ikke kan moderniseres og gøres mere miljøvenlige. Hvis ikke stater som Tyskland går i brechen for ny, miljøvenlig teknik, bliver det sværere at kræve det af ressourcesvage EU-medlemmer.

Denne gennemgang lægger op til tre konklusioner. For det første kan man sætte spørgsmålstegn ved nødvendigheden af den russisk-tyske gasledning, og dens påståede fordele skal man ikke overvurdere. For det andet er miljøproblemerne og sikkerhedsproblemerne så store $\mathrm{og}$ fordelene for de mest udsatte så små, at projektet ikke burde realiseres. Og endelig: Man kunne måske nøjes med at bekymre sig om miljøproblemerne, hvis Rusland var ved at udvikle sig til en normal, demokratisk markedsøkonomi; men det er ikke tilfældet.

Robert Larsson er sikkerhedspolitisk analytiker ved Totalförsvarets forskningsinstitut (FOI) i Stockholm.

Oversat fra suensk af Klaus Carsten Pedersen. 